\title{
Impact of Governance Structure Characteristics of Public-private Partnerships on Smart City Project Success: Evidence from a Multi-case Study in China
}

\author{
Luning Liu \\ Harbin Institute of \\ Technology \\ liuluning@hit.edu.cn
}

\author{
Jingrui Ju \\ Harbin Institute of \\ Technology \\ jjrrui@sina.cn
}

\author{
Yuqiang Feng \\ Harbin Institute of \\ Technology \\ fengyq@hit.edu.cn
}

\author{
Qing $\mathrm{Hu}$ \\ The City University of New \\ York \\ Qing.Hu@baruch.cuny.edu
}

\begin{abstract}
Due to the technological and financial complexity and difficulties of smart city initiatives, the local governments usually adopt a public-private partnership model to govern such projects. This study explores the opportunities and challenges of building smart cities through the public-private partnership (PPP) model. Using an exploratory case study methodology, we interviewed participants in building smart city initiatives across China to develop a theoretical model that captures the essence of such a partnership. Case interview data from three major cities in China were utilized. We analyzed the data of 28 interviews with officials and personnel from public, private, and hybrid organizations involved in smart city projects. Finally, we identified and theoretically validated the following research findings: (1) two key components of the success of smart city initiatives; (2) four key governance structure characteristics of the PPP model that enables the smart city success; (3) two key considerations for establishing the governance structure of a PPP model. The theoretical framework we propose herein can be used to understand the current status and provide guidance for future smart city initiatives.
\end{abstract}

\section{Introduction}

Smart cities are an important IT-enabled innovation in the public sector that has attracted increasing attention from both industry and academia [15]. Smart cities are viewed as a public-private ecosystem with participatory governance and an involvement of nongovernmental stakeholders, which fosters the sustainable economic growth and life quality improvement [3][6]. The definition of smart cities has been transformed from technology-oriented to governance-oriented [3][6][8][9][15] and increasingly more important roles are played by non-governmental stakeholders in the smart cities [2]. Thus, the assessment frameworks for evaluating the performance or success of smart cities have also changed in the same way from mainly focusing on the outcome of the technological infrastructure to additionally emphasizing the roles, benefits, and rights of external stakeholders [21][23]. Though these ideas of governance-oriented assessment have been proposed to be added into the frameworks, such a more integrated framework is still conceptual, not further specifying the key contents of the two assessment dimensions.

Generally, the collaboration between the government and the external stakeholders in the smart cities construction is a type of public-private cooperation. The model of public-private partnerships (PPPs) is commonly used to design, construct, operate, finance, and maintain public infrastructure or public service under the cooperation of some sort of durability between the public and private sectors, in which they jointly develop products and services and share risks, costs, and resources [10][31]. Actually, the model has been widely adopted by traditional e-government initiatives, which has brought many benefits to the government, such as enhanced partnerships, better risk management, improved public facilities and services, and clearer government policies [3]. Nevertheless, it has also generated problems, including cost overruns, unrealistic price and income projections, and legal disputes [19]. Compared with the traditional egovernment initiatives that are relatively simple, involving with one or several private sectors [17], various private sectors participate in the smart city initiatives, making them more complicated and difficult to implement. Specifically, challenges have appeared associated with increasingly obvious and important issues of collective competence and conflict among partners [29]. Though previous studies on the PPPs in the context of e-government provide some important references for research on smart cities, there is still a need to further explore the governance mechanism of PPPs in smart cities, especially the design of an effective PPPs governance structure for the successful development of smart cities. 
Despite certain benefits to the public and private sectors, challenges and issues in PPPs initiatives still exist, which has been evidenced in a number of unsuccessful cases [13]. Hence, the public sectors had to ultimately shoulder the cost of failure, but not the private sectors [19]. Therefore, this study attempts to provide a framework by which leaders and directors of public sectors can design effective governance structures in public-private partnerships to ensure the success of smart city initiatives for their operation and outcomes. More specifically, we aimed to identify and theoretically validate: (1) key components of the success of smart city initiatives; (2) key governance structure characteristics of the PPP model that enable the success of smart cities; (3) key considerations for establishing the governance structure of the PPP model. Our research questions are as follows:

RQ 1: How could the outcomes of smart city initiatives be evaluated?

RQ 2: How do governance structure characteristics of PPPs enable the smart city success?

RQ 3: Why does the local government design such a governance structure of PPPs?

To accomplish our research objectives and lay the foundation for future research on PPP model in the smart city context, we commenced a case study using an exploratory multi-case analysis methodology. In the following sections, we initially review the existing research on smart cities and public-private partnerships. Then, we describe the methodology and the research design in detail and present the evidence we collected, as well as the results of our analyses.

\section{Literature Review}

\subsection{Smart cities}

The concept of smart cities was first proposed in 1994, and since the approval of the Europe 2020 Strategy by the European Commission in 2010 [22], a trend has become increasingly obvious not only in the national support on smart cities projects but also in the number of publications related to this topic [16]. A range of variants in the terms of its definition is a frequent occurrence by replacing "smart" with alternative adjectives, such as "intelligent", "digital", or "ubiquitous". Although the concept of smart cities is widely used, there is still a fuzzy and inconsistent understanding of its meaning. Therefore, a one-sizefits-all definition has not yet appeared [2].

In essence, two mainstreams in the present discussion on the smart city concept can be identified: (1) Technology-oriented strategies that focus on enhancing added-value services delivery and effective resource management for urban administration to citizens based on the efficiency and technological advancement of urban hard infrastructure (i.e., wireless sensor, Internet of Things, cloud computing, and deep learning) [35]; (2) governance-oriented strategies that target the soft infrastructure and citizens, designing conceptual frameworks, models, and methods in terms of urban performance, social and human capital, social innovation, governance, participation and policy on the basis of previous experience and literature on smart cities [1][21]. Other classifications used to categorize the notion for smart cities are the technology-oriented approach vs. the people-oriented approach [1], supplyvs. demand-driven approaches [2], and top-down vs. bottom-up initiatives [5].

\subsection{Public-Private Partnerships (PPPs)}

The concept of public-private partnerships (PPPs) emerged through the inclusion of the private sector in financial projects of the public sector [20]. Due to the specific forms of PPP projects across different nations, various focuses have been placed in defining the PPP concept. For example, informal dialogues between government officials and local community-based organizations are viewed as essential factors for the success of PPPs in the UK, contractual arrangement and shared resources and risks are proposed to define a PPP in the US, and the government of Canada clearly emphasizes the importance of the match between expertise and public needs [31]. Besides, a definition of PPP from the perspective of an institution is proposed as "cooperation of some sort of durability between public and private sectors in which they jointly develop products and services and share risks, costs, and resources which are connected with these products" [32], which is viewed as a relatively formal definition because of the inclusion of three key components of PPP: durable cooperation, risk sharing, and joint production [10].

The existing literature related to PPPs is fragmented among several diverse research streams, including organizational economics, public administration, and project management [10]. The academic focus has been concentrated mostly on economic issues, such as contract incompleteness and transaction and agency costs [12], or explored how to balance collective and specific interests in PPP through political institutions and political incentives [7]. Some studies found that PPPs are a fundamentally new organizational form [27], and the frictions among the partners in this new organizational form may lead to vital issues and unintended consequences [11]. Therefore, further discussion on the management of such structures has been carried out to investigate the governance mechanisms in PPPs [24]. However, governance issues associated with the PPP project in the context of smart cities are often more complicated 
compared with the ones in the E-government, which, therefore, need to be addressed in further research.

\section{Methods}

\subsection{Research design and methodology}

Using the inductive approach for theory-building [34], in this research, we discuss the findings of a multi-case study. Given the limited number of investigations on the influence of the governance structure of public-private partnerships on the success of smart cities projects, the positivist case study approach has the potential to generate valuable insights. Conducting a case study is especially useful for developing theoretical insights when a phenomenon has not been well studied, or the research focuses on areas in which the current perspectives seem inadequate [25].

Since there are a number of types of public-private partnership models [10], and cities also vary in terms of population, acreage, region and GDP, it is critical that a multi-case design is adopted for such a study to achieve a certain degree of generalizability of its findings.

\subsection{Case selection}

In this study, we adopted a purposive sampling strategy [6] to determine the case cities that span different sizes, regions, and PPP model settings, which increases generalizability. Based on an annual report on smart cities announced by the National Development and Reform Commission of China in 2017, our research team first approached several cities from the top 20 ranking list that had won the national best smart city case awards to solicit participation. Finally, three cities agreed to participate. In this paper, we named them SZ, NJ, and YC for anonymity.

The first city, SZ, is one of the top four first-tier cities in China. It is located in the Southern China region, which is famous for its high-tech industry and rapid economic growth. The second city is $\mathrm{NJ}$, located in the East China region, which is one of the 15 subprovincial cities in China. NJ is the capital city of JS Province, which is in the second place in terms of province-level GDP in China in 2017. The third city is YC, which is located in an economically underdeveloped region in China, the Western China region. $\mathrm{YC}$ is one of the largest cities in that region, while it is also the capital city of NX Province.

\subsection{Site visits and interviews}

Before the actual site visits started, a research protocol was developed that specified the ideal profiles of organizations and individuals, the interview protocol, and the open-ended questions, based on the literature and the focal phenomenon of interest. The study focused on governance structure characteristics of
PPPs as a starting point and then investigated the antecedents and consequences of these governance structure characteristics which could contribute to the success of smart city initiatives.

Three researchers conducted the interviews from October to November 2017. One led the discussion and pursued the directions proposed by the interviewees, whereas the others took notes and asked additional questions. Respondents that were representatives of different stockholders in each city were interviewed, such as city government officials, general contractors, and private partners. All interviews lasted approximately 45-60 $\mathrm{min}$; the longest interview continued for more than two hours. All interviews were recorded using a digital recorder and then transcribed into manuscripts that were employed for the qualitative data analysis. Additional archival data such as introductions and reports on the case cities' smart city projects were also collected to minimize the retrospective bias. Finally, a total number of 28 interviews of participants from 12 organizations in 3 cities were completed in 2017 (Table 1).

Table 1. Profiles of the interviewees.

\begin{tabular}{|c|c|c|c|c|}
\hline City & $\begin{array}{l}\text { \# of } \\
\text { Interviewees }\end{array}$ & $\begin{array}{l}\text { Type of } \\
\text { organization }\end{array}$ & $\begin{array}{l}\text { Name of } \\
\text { organization }\end{array}$ & $\begin{array}{l}\text { Descriptions of } \\
\text { Interviewees }\end{array}$ \\
\hline \multirow{4}{*}{ SZ } & \multirow{4}{*}{9} & \multirow{2}{*}{$\begin{array}{l}\text { City } \\
\text { Government } \\
\text { Officials }\end{array}$} & $\begin{array}{l}\text { SZ Municipal } \\
\text { Commission of } \\
\text { Economic and } \\
\text { Trade and } \\
\text { Information }\end{array}$ & $\begin{array}{l}\text { Director of smart } \mathrm{SZ} \\
\text { project }(\mathrm{N}=1)\end{array}$ \\
\hline & & & $\begin{array}{l}\text { SZ Municipal E- } \\
\text { government } \\
\text { Resources Center }\end{array}$ & $\begin{array}{l}\text { Director, Associate } \\
\text { Director, and a } \\
\text { project manager (N } \\
=3 \text { ) }\end{array}$ \\
\hline & & \multirow{2}{*}{$\begin{array}{l}\text { Private } \\
\text { partners }\end{array}$} & $\begin{array}{l}\text { SZ Audaque Data } \\
\text { Technology Ltd. }\end{array}$ & $\begin{array}{l}\mathrm{VP} \text { and a project } \\
\text { manager }(\mathrm{N}=2)\end{array}$ \\
\hline & & & $\begin{array}{l}\text { SZ ZHZX } \\
\text { Information } \\
\text { Technology Ltd. }\end{array}$ & $\begin{array}{l}\text { VP, CTO, and } \\
\text { Marketing Director } \\
(\mathrm{N}=3)\end{array}$ \\
\hline \multirow{4}{*}{ NJ } & \multirow{4}{*}{8} & $\begin{array}{l}\text { City } \\
\text { Government } \\
\text { Officials }\end{array}$ & $\begin{array}{l}\text { NJ Municipal } \\
\text { Commission of } \\
\text { Development and } \\
\text { Reform }\end{array}$ & $\begin{array}{l}\text { Director and } \\
\text { Associate Director } \\
\text { of smart NJ project } \\
(\mathrm{N}=2)\end{array}$ \\
\hline & & $\begin{array}{l}\text { General } \\
\text { Contractor }\end{array}$ & $\begin{array}{l}\text { NJ information } \\
\text { Klc Holdings Ltd. }\end{array}$ & $\begin{array}{l}\mathrm{CEO} \text { and } \mathrm{CFO}(\mathrm{N}= \\
\text { 2) }\end{array}$ \\
\hline & & \multirow{2}{*}{$\begin{array}{l}\text { Private } \\
\text { partners }\end{array}$} & $\begin{array}{l}\text { NJ ZJSY } \\
\text { Information } \\
\text { Technology Co., } \\
\text { Ltd. }\end{array}$ & $\mathrm{VP}(\mathrm{N}=1)$ \\
\hline & & & $\begin{array}{l}\text { NJ KH Wireless } \\
\text { Network } \\
\text { Communication } \\
\text { Co., Ltd. }\end{array}$ & $\begin{array}{l}\mathrm{VP} \text { and two project } \\
\text { managers }(\mathrm{N}=3)\end{array}$ \\
\hline \multirow{4}{*}{ YC } & \multirow{4}{*}{11} & \multirow{2}{*}{$\begin{array}{l}\text { City } \\
\text { Government } \\
\text { Officials }\end{array}$} & $\begin{array}{l}\text { YC Municipal } \\
\text { Big Data Service } \\
\text { and Management } \\
\text { Bureau }\end{array}$ & $\begin{array}{l}\text { Director, Associate } \\
\text { Director and two } \\
\text { project managers ( } \mathrm{N} \\
=4)\end{array}$ \\
\hline & & & $\begin{array}{l}\text { YC Citizen } \\
\text { Center }\end{array}$ & $\begin{array}{l}\text { IT manager and two } \\
\text { employees }(\mathrm{N}=3)\end{array}$ \\
\hline & & $\begin{array}{l}\text { General } \\
\text { contractor }\end{array}$ & $\begin{array}{l}\text { ZTE (YC) } \\
\text { Intellectual } \\
\text { Industry Co., Ltd. }\end{array}$ & $\begin{array}{l}\mathrm{VP} \text { and a project } \\
\text { manager }(\mathrm{N}=2)\end{array}$ \\
\hline & & $\begin{array}{l}\text { Private } \\
\text { partners }\end{array}$ & $\begin{array}{l}\text { ZTE (YC) Smart } \\
\text { City Research } \\
\text { Institute }\end{array}$ & $\begin{array}{l}\mathrm{VP} \text { and a project } \\
\text { manager }(\mathrm{N}=2)\end{array}$ \\
\hline
\end{tabular}




\section{Findings}

The theoretical model that was developed based on our interviews and qualitative data analysis is illustrated in Figure 1. First, we found that the success of smart city initiatives is reflected by two key components, including data integration-oriented performance and citizen service-oriented performance. Second, four key governance structure characteristics of the PPP model were identified that enabled the smart city success, including top-level planning of the local government, government-dominant infrastructure construction, hybrid organizational platform as a general contractor, and deep involvement of a large number of private partners. Especially, the top-level planning of the local government and hybrid organizational platform as a general contractor exerted a positive impact on data integration-oriented performance, while the government-dominant infrastructure construction and the deep involvement of multiple private partners positively affected citizen service-oriented performance. Finally, drawing on the transaction cost theory, we established that the concerns of the communication-related and relationrelated cost are two critical considerations for establishing the governance structure of a PPP model.

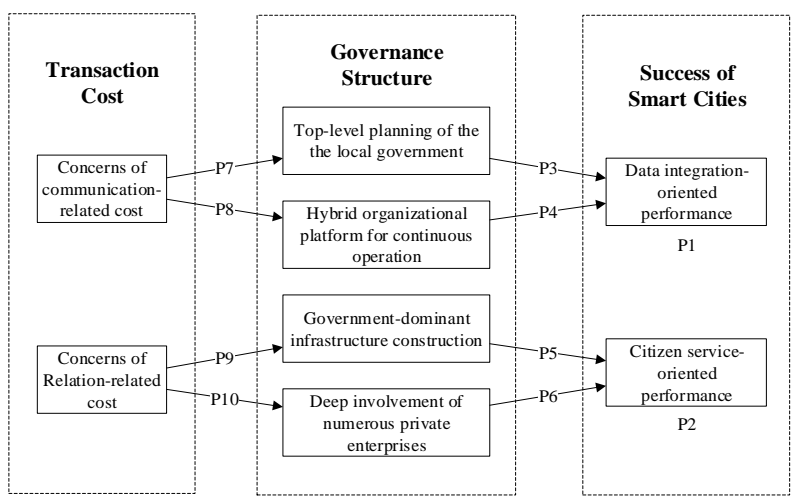

Figure 1. Theoretical model.

The proposed theoretical model not only reflects the key factors that discriminate the success of the cases but also joins together several areas of research that have been largely unconnected until now. In the present study, we have made propositions on these relations to better understand the essence of publicprivate partnerships in smart city projects.

\subsection{Components of smart cities projects success}

All the case cities in our study implemented a number of smart city practices (e.g., smart transportation, smart community, smart tourism, etc.) to a certain success level. This is not a surprise since all the case cities included were selected among the top 20 smart cities in China and expectedly had to achieve a higher-level performance of smart city initiatives. However, during the interviews and the post-hoc review of the transcripts, two key components of the success of smart city initiatives were clearly identified, including data integration-oriented and citizen serviceoriented performances. These two components reflect the two completely different perspectives of the outcomes of smart city initiatives. Therefore, cities may just achieve a higher-level performance from one certain perspective which could not directly transfer into the other perspectives. However, some cities may be able to achieve a higher-level performance from both perspectives. In every city we visited, the interviewees largely confirmed the two components although some cities performed well based just only on one of the two. A summary of the performances of the smart cities projects in the case cities is given in Table 2.

Table 2. Summary of the performance of the case cities in smart city projects.

\begin{tabular}{|c|c|c|}
\hline \multirow{2}{*}{ City } & \multicolumn{2}{|c|}{ Components of smart cities projects success } \\
\cline { 2 - 3 } & $\begin{array}{c}\text { Data integration-oriented } \\
\text { performance }\end{array}$ & $\begin{array}{c}\text { Citizen service-oriented } \\
\text { performance }\end{array}$ \\
\hline NJ & High & High \\
\hline SZ & Low & High \\
\hline YC & High & Low \\
\hline
\end{tabular}

\subsubsection{Data integration-oriented performance}

Smart city projects encompass various data formats using a wide variety of intelligent objects embedded throughout the city. However, the vision of the smart city is to integrate a large amount of data from multiple sources; data integration within a smart city is one of the important challenges to be addressed [9]. In recent years, several technologies have been integrated into smart cities, which reduce the technical barriers to addressing data. An analysis of the interview transcripts showed that the leaders and directors of smart city projects viewed data integration as a key measurement of the success of smart cities.

The Director of NJ Municipal Commission of Development and Reform had placed a strong focus on the importance of data integration in a smart city project. According to him, NJ has achieved a high level of data integration during the progress of the smart city project:

"As early as the process of planning for smart cities, we realized that data integration was the most important task. Comparing with other cities, our work on government data integration started relatively earlier in China."

The Director and project manager of YC Municipal Big Data Service and Management Bureau also expressed a similar view.

"Although there are ten modules in the smart city project of our city, the association among these modules is extremely high. Our design of the smart city 
project is relatively comprehensive with a relatively high degree of integration, which actually solves the problem of information isolation."

In our study, we define data integration-oriented performance as the degree about how a large amount of data from multiple sources is integrated in smart city projects. To summarize, all of the three case cities asserted that a high level of data integration was a key indicator of smart city success. However, based on the statement of different stakeholders of smart city initiatives in the three case cities, NJ and YC had achieved a higher level of data integration, whereas the data integration of SZ was still at a lower level. Thus, herein, we propose that:

Proposition 1: Data integration-oriented performance is a key component of the success of smart city initiatives.

\subsubsection{Data integration-oriented performance}

The original intention of smart city projects was to help the local government better govern the city by the operation of abundant IOT equipment. However, the ultimate objective of smart city projects is to help the government improve their public services and then deliver these services to citizens [23]. An analysis of the interview transcripts suggested that the leaders and directors of smart city projects viewed citizen services as a key measurement of smart cities success.

For example, the Associate Director of $\mathrm{NJ}$ information Klc Holdings Ltd. stated that citizen service was a critical outcome of the smart city project:

"I think that the most fundamental task (of a smart city) is to help our citizens and make the citizens feel usefulness. Concerning the smart city project, the satisfaction of the citizens is much more important than that of government officials. It is true in NJ City at least. These local government officials of NJ are exceedingly concerned about the evaluation from their service recipients (citizens)."

According to the evidence in our case interviews, SZ City has achieved a relatively higher level of citizen service-oriented performance in smart city projects. As the Director of the smart SZ project in the SZ Municipal Commission of Economic and Trade and Information noted:

"Smart cities should be constructed from the perspective of the citizens...The service objects of smart cities are the citizens. This must be clearly recognized. That is why the citizens' satisfaction from the smart SZ project is high. All applications are convenient to use by the citizens."

To summarize, a high level of citizen service was confirmed as a key indicator of smart city project success in all three case cities. However, compared to the cities achieving a higher level of citizen service, citizen service-oriented performance in $\mathrm{YC}$ was still at a lower level. In our study, we define citizen serviceoriented performance as the degree about how much the value of smart city applications could be perceived by the citizens. Thus, we propose that:

Proposition 2: Citizen service-oriented performance is a key component of the success of smart city initiatives.

\subsection{Characteristics of the critical governance structure of the PPP model implemented and its impact on the smart city success}

After we found two key components of the success of smart city initiatives, some interesting questions should follow: "Why did a city reach a higher level of one component but a lower level of another other?" and "Why was a city successful from the perspectives of the two components?" We may additionally ask "What are the differences on the governance structures of PPPs among these cities with different outcomes of smart city initiatives?" A cross-case analysis of the interview transcripts showed that there were four critical governance structure characteristics of the PPP model that drove cities towards higher levels of smart city success. The cross-case comparative evidence on how governance structure characteristics of PPPs enable the smart city success is displayed in Table 3.

Table 3. Summary of the relationships between the characteristics of the governance structure of the PPP model and smart city success

\begin{tabular}{|c|c|c|c|c|c|c|}
\hline \multirow[t]{2}{*}{ City } & \multicolumn{4}{|c|}{$\begin{array}{c}\text { Key governance structure characteristics of PPP } \\
\text { model }\end{array}$} & \multicolumn{2}{|c|}{$\begin{array}{r}\text { Key components of } \\
\text { smart city success }\end{array}$} \\
\hline & $\begin{array}{l}\text { top-level } \\
\text { planning } \\
\text { of the } \\
\text { local } \\
\text { governm } \\
\text { ent }\end{array}$ & $\begin{array}{l}\text { hybrid } \\
\text { organizatio } \\
\text { nal } \\
\text { platform as } \\
\text { a general } \\
\text { contractor }\end{array}$ & $\begin{array}{l}\text { governme } \\
\text { nt- } \\
\text { dominant } \\
\text { infrastruct } \\
\text { ure } \\
\text { constructi } \\
\text { on }\end{array}$ & $\begin{array}{l}\text { deep } \\
\text { involve } \\
\text { ment of } \\
\text { numerou } \\
\text { s private } \\
\text { partners }\end{array}$ & $\begin{array}{l}\text { data } \\
\text { integrati } \\
\text { on- } \\
\text { oriented } \\
\text { perform } \\
\text { ance }\end{array}$ & $\begin{array}{l}\text { citizen } \\
\text { service- } \\
\text { orientec } \\
\text { perform } \\
\text { ance }\end{array}$ \\
\hline $\mathrm{NJ}$ & $\checkmark$ & $\checkmark$ & $\checkmark$ & $\checkmark$ & High & High \\
\hline SZ & $x$ & $x$ & $\checkmark$ & $\checkmark$ & Low & High \\
\hline $\mathrm{YC}$ & $\begin{array}{lll} & & \\
\end{array}$ & $\checkmark$ & $x$ & $x$ & High & Low \\
\hline
\end{tabular}

\subsubsection{Top-level planning of the local government}

The capability of top-level planning is critical to the organizations which attempt to implement information systems [29]. The logic is similar for the cities in which the construction of smart cities is underway. The local government needs to define a long-term plan of smart cities since it plays a general leadership role in the smart city project. A top-level long-term plan of the development of smart cities should be designed by considering how to meet the requirements of all of governmental departments in the local government and how to integrate these various requirements. Furthermore, there should be a specific department in the local government assigned and empowered to be a lead organization to work out and implement the top-level plan of the smart city. 
The Director of NJ Municipal Commission of Development and Reform confirmed that they were playing the general leadership role in the smart NJ project. Furthermore, he expressed the notion that the top-level plan is a critical enabler of the success of the smart NJ project.

"At the beginning of the smart city project, we set up two fundamental rules. The first one was that the NJ Municipal Commission of Development and Reform should be responsible for top-level planning and coordination. Moreover, the second one is that private capital that should play an important role...I think the reason of our success is that we have had a clear strategic plan with a top-level design."

In this study, we define top-level planning of the local government as a long-term plan of smart cities project should be designed at top-level by a lead governmental organization. According to our crosscase analysis based on interview evidence, $\mathrm{NJ}$ and YC highlighted the importance of the top-level planning of the local government in smart city projects. Both cities had set up an institutional guarantee to facilitate such a top-level planning and ensure the leadership position of the local government. The local government of NJ assigned a specific department, NJ Municipal Commission of Development and Reform, as a lead organization to be responsible for the planning and managing of the smart city project, while the local government of YC founded a new department, named YC Municipal Big Data Service and Management Bureau, to be the lead organization of the smart YC project. However, SZ failed to select the lead organization so that there was a lack of top-level planning of the smart SZ project. On the contrary, each governmental department developed its own plan about the smart city according to its own requirements only. This scheme gradually caused considerable difficulties for the local government of SZ to integrate various smart city applications from different fields. As a result, the data integration-oriented performance of the smart city project was at a relatively higher level in $\mathrm{NJ}$ and YC, but it was still at a lower level in SZ. A clear toplevel designed plan could provide an integrative vision and a consistent standard for all governmental departments to develop their smart city applications, which will eventually facilitate the data integration, which is a fundamental component of the smart city success. Thus, we suggest:

Proposition 3: Cities with a top-level planning are more likely to achieve a high-level data integration-oriented performance in a smart city project.

\subsubsection{Hybrid organizational platform as a general contractor}

Public-private partnerships require a hybrid collaboration which could coordinate and align performance across public and private partners [4]. In the context of smart city projects, such hybrid collaboration is even more important due to the complexity in governance. Some studies highlighted the central role of the hybrid organizations in publicprivate partnerships [14][30]. According to [33], hybrid organizations played an intermediate role to reduce the transaction cost between public and private sectors. In our study, the case evidence suggested that a hybrid organizational platform was a critical governance structure characteristic of the PPP model which could enable the smart city success especially from the perspective of data integration-oriented performance.

The Director of YC Municipal Big Data Service and Management Bureau confirmed that the local government of $\mathrm{YC}$ founded a hybrid organization as a platform to participate in calls for bids in the smart YC project.

"For the implementation of smart city projects, we (the municipal government) established a joint venture company named ZTE (YC) Intellectual Industry Co., Ltd., in which investments were made by the municipal government and ZTE Communication Company. In fact, this company plays a general contractor role in the smart city project. We realize the top-level planning and design of the smart city project first. After that, ZTE (YC) Intellectual Industry Co., Ltd. is responsible for calling for bids. Because the stock right of this company is held by both the government and ZTE, they are strategic cooperation partners."

In this research, we define hybrid organizational platform as a general contractor as a hybrid organizational platform should be founded and assigned as a general contractor of the smart city project. According to the results of our cross-case analysis based on interview evidence, the critical role of the hybrid organizational platform as a general contractor in smart city projects has been highlighted in both $\mathrm{NJ}$ and $\mathrm{YC}$ projects A new company was set up in the two cities according to the hybrid organizational form to facilitate the collaboration between public and private sectors. Therefore, in NJ and YC, the top-level planning of the local government could be more easily understood and implemented by private companies with the hybrid organizational platforms serving as a broker [29]. As a result, the data integration-oriented performance of smart city project was at a relatively higher level in $\mathrm{NJ}$ and $\mathrm{YC}$, whereas it was still at a lower level in SZ, where no such a hybrid organization acting as a general contractor was available. Thus, we propose the following: 
Proposition 4: Cities with a hybrid organizational platform as a general contractor are more likely to achieve a high-level data integrationoriented performance in smart city projects.

\subsubsection{Government-dominant infrastructure construction}

Infrastructure construction is the primary task at the initial stage of smart city projects. The public smart city platform and application systems could be constructed based on the existing public infrastructure. As a subsequent stage of the smart city project, the application systems for smart cities should be privatedominant and developed based on the PPPs model since private companies use more advanced technologies and customer services than the governmental ones. However, there are two major categories for infrastructure construction serving as a foundation of smart cities: government-dominant and private-dominant. The results of our case interviews revealed that $\mathrm{NJ}$ and $\mathrm{SZ}$ adopted government-dominant infrastructure construction, whereas a private-dominant infrastructure construction was used in YC.

The Associate Director of SZ Municipal Egovernment Resources Center confirmed that the infrastructures of the smart SZ projects implemented were fully funded by the SZ government.

"All of the smart SZ projects openly invited bids according to a standard procedure. The eligible companies were welcome to participate in the bidding, and each company had a fair opportunity to win the bidding as long as it qualified. The SZ government fully provided the investment for the infrastructure construction of the smart city without joint venture or any other financial support from private capital."

In our study, we define government-dominant infrastructure construction as the infrastructures of the smart city should be mainly invested and owned by the local government. According to our cross-case analysis based on interview evidence, shown in Table 3, both $\mathrm{NJ}$ and SZ adopted government-dominant infrastructure construction, and the citizen serviceoriented performance of smart city project was at a relatively higher level in NJ and SZ. On the contrary, private-dominant infrastructure construction was utilized in YC, and its citizen service-oriented performance of the smart city project was at a relatively lower level. We speculate that if the local government had invested and owned the infrastructure, then it would have been much easier for the government to select some good-quality private companies to provide smart city application services to the citizens. However, if the local government had lost the control power of the smart city infrastructure, then the quality of the citizen services could not have been guaranteed without the general control of the local government. Thus, we suggest the following:

Proposition 5: Cities with government-dominant infrastructure construction are more likely to achieve a high-level citizen service-oriented performance in smart city projects.

\subsubsection{Deep involvement of numerous private} partners

It is critical to adopt a network constitution strategy to improve the outcome of PPPs by introducing alternatives to facilitate the search for quality [18]. As new institutional arrangements to provide services for their citizens, the government should involve numerous private partners to keep alternatives available in public-private partnerships. Therefore, we considered that the involvement of a great number of private partners was another critical governance structure characteristic of PPPs.

In our case interview, the $\mathrm{CEO}$ of $\mathrm{NJ}$ information Klc Holdings Ltd. confirmed our viewpoint by sharing how they attracted more technology-leading private partners.

"The roles of private capitals in our platform are two-fold. First, they have very strong research and development capabilities. Second, they have a relatively strong capacity to expand their resources. Therefore, our company's objective is to attract more private capitals to be involved in the smart city project to play their important roles."

In our study, we define deep involvement of numerous private partners as the local government should attract numerous private partners get involved in the smart city project. According to the findings of our cross-case analysis based on interview evidence, both $\mathrm{NJ}$ and $\mathrm{SZ}$ attracted numerous private partners to become involved in the smart city project, which contributed to achieving relatively higher levels of their citizen service-oriented performances of the smart city projects. In contrast, only one private partner participated in the smart YC project, and, accordingly, its citizen service-oriented performance was at a relatively lower level. We noted that the large number of private partners involved allowed for a positive competition, which subsequently guaranteed the high quality of citizen services provided by the private partners. Thus, we propose the following:

Proposition 6: Cities with deep involvement of numerous private partners are more likely to achieve a high-level citizen service-oriented performance in smart city projects.

\subsection{Antecedents of governance structure characteristics of PPP model: a transaction cost view}


After we identified four critical governance structure characteristics of the PPP model that drove cities towards higher levels of smart city success, another interesting and important question followed: "Why does the local government design such a governance structure of PPPs?" Based on a cross-case analysis of the interview transcripts, two constructs from the viewpoint of transaction cost economics (TCE) were established, communication-related and relationrelated costs.

\subsubsection{Communication-related cost}

Due to the natural gap between public and private sectors, their effective communication and mutual understanding is a critical issue in the public-private partnerships model [28]. According to our cross-case analysis of the interview transcripts, the concerns about the communication-related cost were identified as an antecedent of the design of the governance structure of PPPs. In our study, we define communication-related cost as the cost caused by ineffective communication and misunderstanding between public and private sectors.

When explaining why top-level planning is critical in PPPs, the IT manager of YC Citizen Center mentioned the concerns about the communicationrelated cost.

"In the smart YC project, the misunderstanding between our governmental departments and ZTE is always significant. It takes a long time for us to understand each other's thoughts. If we fail to propose a long-term strategic plan, the time we waste in communication will be even longer."

When explaining why they put a lot of efforts in designing a top-level planning, the Director of $\mathrm{NJ}$ Municipal Commission of Development and Reform expressed a similar view that a clear top-level planning could significantly reduce the communication-related cost in public-private partnerships. Thus, we suggest the following proposition:

Proposition 7: Cities with higher concerns about the communication-related cost are more likely to perform top-level planning in smart city projects.

When asked why they founded a hybrid organization as a general contractor of the smart NJ project, the Director of NJ Municipal Commission of Development and Reform explained the reason.

"The hybrid organization can efficiently communicate with the government because there is public capital in the company, whereas it is probably inefficient for the pure private enterprise as it needs to spend a longer period of time and higher costs to understand the idea of the government."

Our case interview evidence clearly suggested that the concerns about the communication-related cost might cause the government design a hybrid organizational platform to facilitate the communication between public and private sectors. Our finding is consistent with the studies note the importance of the brokers in the PPP projects [29]. Thus, we suggest the following proposition:

Proposition 8: Cities with higher concerns about the communication-related cost are more likely to design a hybrid organizational platform as the general contractor in smart city projects.

\subsubsection{Relation-related cost}

Public-private partnerships are often difficult to organize because of disparate goals, incentives, and management practices. Relational coordination reflects how the coordination of these social and work relationships is viewed as a critical factor affecting task performance and the creation of social value in publicprivate collaborations [4]. However, in our study, the cross-case analysis of the interview transcripts suggested that the extra dependence between the public and private sectors might lead to a negative outcome. If there are too many financial interests among different, the outcome of a project is rather difficult to control. We found that the local government usually considered avoiding the extra-dependent relationship between public and private sectors when designing the governance structure of PPPs in smart city projects. We named this consideration a relation-related cost.

The Director of SZ Municipal Commission of Economic and Trade and Information expressed his concerns about the extra-dependent relationships between public and private sectors.

"SZ government has sufficient funding to invest into the infrastructure construction of smart city projects. We don't need the private companies get involved into the infrastructure construction. Otherwise, we will lose the control of the smart city projects."

Thus, we suggest the following proposition:

Proposition 9: Cities with higher concerns about relation-related cost are more likely to adopt a government-dominant infrastructure construction in smart city projects.

When explaining why the involvement of numerous of private partners is critical in PPPs, the Director of SZ Municipal Commission of Economic and Trade and Information mentioned their concerns about the relation-related cost.

"We need to attract more and more private companies to join the smart SZ project. The more private partners we have, the more confident we are. Suppose if we have only one private partner, regardless of how bad the performance is, we have to accept it. However, if we have a great number of partners, we could easily stop the collaboration with the partner performing poorly." 
Thus, we suggest the following proposition:

Proposition 10: Cities with higher concerns about relation-related cost are more likely to involve numerous private partners in smart city projects.

\section{Discussion}

\subsection{Theoretical Contributions}

From the perspective of theory development, this study is among the first of the studies on evaluating smart city initiatives from a governance perspective, instead of from the technological perspective as has been done and described in the existing literature until now [6][8]. Since the definition of smart cities has been transformed from technology-oriented to governance-oriented [3][6][8][9], it is critical to transform the assessment frameworks for evaluating the performance or success of smart cities in the same way [21][23]. Our findings on the two key components of the success of smart city initiatives provide a solid theoretical foundation for developing a governanceoriented assessment framework.

Second, the importance of the governance structure of PPPs has been rarely focused on in the existing studies [18] [28]. Hence, this study examines its effect and extends the extant literature by identifying certain key governance structure characteristics based on the cross-case evidence obtained. By comparing the case interview data from 3 case cities, our research findings show how the governance structure characteristics of PPPs enable the smart city success. Therefore, this study is among the first of the studies on specifying the key governance structure characteristics of PPPs and their relationships with success of smart cities.

Third, our study not only reflects the key factors that discriminate the success of the cases but also joins together several theories that have been largely unconnected. For example, drawing on the transaction cost theory, this research identifies two new constructs related to the transaction cost, concerns about the communication-related and relation-related costs, to explain the considerations for establishing the governance structure of the PPP model. Furthermore, based on our case evidence, we propose the specific relationships between transaction cost and governance structure of the PPPs. This study extends the existing literature about transaction cost in PPPs from the perspective of economics to organization science.

\subsection{Practical implications}

From a managerial perspective, this study offers some prescriptive guidance for understanding the currently ongoing and guide future smart city initiatives. The theoretical framework we propose clearly show the path to smart cities projects success.
Drawing on our theoretical framework, we could provide some suggestions for the cities where the smart city projects have great potentials for making further progress, such as SZ and YC. On one hand, because the data integration-oriented performance of smart SZ project is still weak, we suggest the SZ government select or found a governmental organization which is responsible for top-level planning of the smart SZ project. Moreover, a hybrid organizational platform should be founded and assigned as a general contractor of the smart SZ project. On the other, since the citizen service-oriented performance of smart YC project is still at a lower level, we suggest the YC government reconsider their relation with ZTE. In order to break monopoly and introduce competition, the YC government needs to attract more private partners get involved in the smart YC project.

\section{Conclusion}

The multi-case analysis integrates several literature streams to develop a theoretical framework that helps us better understand the governance structure of PPPs in the context of a smart city. The case data facilitates the identification of the concepts in different literature streams and connect them. Our research findings are threefold. First, we found that data integration-oriented and citizen service-oriented performances are two key components of the success of smart city initiatives. Second, we discovered that four key governance structure characteristics of PPP models enable the success of smart city programs: top-level planning by the local government, government-dominant infrastructure construction, hybrid organizational platform as a general contractor, and deep involvement of numerous private partners. Especially, the top-level planning by the local government and the use of a hybrid organizational platform as a general contractor exert a positive impact on data integration-oriented performance. Furthermore, the government-dominant infrastructure construction and deep involvement of numerous private partners positively affect citizen service-oriented performance. Finally, drawing on transaction cost theory, we found that the concerns about the communication-related and relation-related costs are two critical considerations for establishing the governance structure of PPP model.

Similar to most studies, this research is not without limitations. The research is based on a purposive sample from three cities for the development of propositions and a theory for future testing. The qualitative research study has only focused on the smart city projects in China. Therefore, investigations on a wider array of countries would improve the generalizability of the results. 


\section{Acknowledgements}

This research was supported by the National Natural Science Foundation of China [91646105, 71781220619, 71429001, 71472053]; the Postdoctoral Science Foundation of China [2014M550198, 2015T80363]; and the China Scholarship Council [201706120223, 201706125025].

\section{References}

[1] Angelidou, M. (2014). Smart city policies: A spatial approach. Cities, 41, S3-S11.

[2] Angelidou, M. (2015). Smart cities: A conjuncture of four forces. Cities, 47, 95-106.

[3] Ball, M., \& Maginn, P. J. (2005). Urban change and conflict: Evaluating the role of partnerships in urban regeneration in the UK. Housing Studies, 20(1), 9-28.

[4] Caldwell, N. D., Roehrich, J. K. and George, G. (2017) Social Value Creation and Relational Coordination in Public Private Collaborations, Journal of Management Studies, 56 (6), 906-928.

[5] Calzada, I., \& Cobo, C. (2015). Unplugging: Deconstructing the smart city. Journal of Urban Technology, 22(1), 23-43.

[6] Caragliu, A., Del Bo, C., \& Nijkamp, P. (2011). Smart cities in Europe. Journal of urban technology, 18(2), 65-82.

Eisenhardt, K.M., 1989. Making fast strategic decisions in highvelocity environ-ments. Acad. Manage. J. 32, 543-576.

[7] Engel, E., Fischer, R. D., \& Galetovic, A. (2014). The economics of public-private partnerships: A basic guide. Cambridge University Press.

[8] Europea, C. (2012). Communication from the Commission: Smart Cities and Communities-European Innovation Partnership. EIP-SCC, Brussels, 10, 2012.

[9] Harrison, C., Eckman, B., Hamilton, R., Hartswick, P., Kalagnanam, J., Paraszczak, J., \& Williams, P. (2010). Foundations for smarter cities. IBM Journal of Research and Development, 54(4), 1-16.

[10] Hodge, G. A., \& Greve, C. (2007). Public-private partnerships: an international performance review. Public administration review, 67(3), 545-558.

[11] Hoppe, E. I., Kusterer, D. J., \& Schmitz, P. W. (2013). Public-private partnerships versus traditional procurement: An experimental investigation. Journal of Economic Behavior \& Organization, 89, 145-166.

[12] Iossa, E., \& Martimort, D. (2015). The simple microeconomics of public - private partnerships. Journal of Public Economic Theory, 17(1), 4-48.

[13] Jamali, D. (2004). Success and failure mechanisms of public private partnerships (PPPs) in developing countries: Insights from the Lebanese context. International Journal of Public Sector Management, 17(5), 414-430.

[14] Jay, J. (2013) Navigating Paradox as a Mechanism of Change and Innovation in Hybrid Organizations, Academy of Management Journal, 56 (1).

[15] Ju, J. R., Liu, L. N. \& Feng, Y. Q. (2018) Citizen-centered big data analysis-driven governance intelligence framework for smart cities. Telecommunications Policy, forthcoming.

[16] Jucevičius, R., Patašienè, I., \& Patašius, M. (2014). Digital dimension of smart city: critical analysis. Procedia-Social and Behavioral Sciences, 156, 146-150.

[17] Kivleniece, I., \& Quelin, B. V. (2012). Creating and capturing value in public-private ties: A private actor's perspective. Academy of Management Review, 37(2), 272-299.
[18] Klijn, E-H., \& Teisman, G. R. (2000). Governing publicprivate partnerships: Analysing and managing the processes and institutional characteristics of public-private partnerships. In P. Osborne (Ed.), Public-private partnerships: Theory and practice in international perspective (pp. 165-186). London: Routledge.

[19] Kumaraswamy, M. M., \& Zhang, X. Q. (2001). Governmental role in BOT-led infrastructure development. International Journal of Project Management, 19(4), 195-205.

[20] Li, B., \& Akintoye, A. (2003). An overview of publicprivate partnership. Public-private partnerships: managing risks and opportunities, 1-30.

[21] Lombardi, P., Giordano, S., Farouh, H., \& Yousef, W. (2012). Modelling the smart city performance. Innovation: The European Journal of Social Science Research, 25(2), 137-149.

[22] Marlier, E. (2010). Europe 2020: towards a more social EU? (No. 69). Peter Lang.

[23] Marsal-Llacuna, M. L. (2017). Building Universal Sociocultural Indicators for Standardizing the Safeguarding of Citizens' Rights in Smart Cities. Social Indicators Research, 130(2), 563-579.

[24] Medaglia, R., Hedman, J., \& Eaton, B. (2017). PublicPrivate Collaboration in the Emergence of a National Electronic Identification Policy: The Case of NemID in Denmark. In System Sciences (HICSS), 2017 50th Hawaii International Conference on (pp. 2782-2791). IEEE.

[25] Paré. (2004) Investigating information systems with positivist case research. Communications of the Association for Information Systems 13 (1):18.

[26] Patton, M., 1990. Qualitative Data Analysis, 2nd ed. Sage Publications, ThousandOaks, CA.

[27] Rao, H., Morrill, C., \& Zald, M. N. (2000). Power plays: How social movements and collective action create new organizational forms. Research in organizational behavior, 22, 237-281.

[28] Rufin, C., \& Rivera-Santos, M. (2012). Between commonweal and competition: Understanding the governance of public-private partnerships. Journal of Management, 38(5), 1634-1654.

[29] Ruuska, I., \& Teigland, R. (2009). Ensuring project success through collective competence and creative conflict in publicprivate partnerships-A case study of Bygga Villa, a Swedish triple helix e-government initiative. International Journal of Project Management, 27(4), 323-334.

[30] Skelcher, C. and Smith, S. R., (2015) Theorizing hybridity: Institutional logics, complex organizations, and actor identities: The case of nonprofits, Public Administration, 93 (2), 433-448.

[31] Tang, L., Shen, Q., \& Cheng, E. W. (2010). A review of studies on public-private partnership projects in the construction industry. International Journal of Project Management, 28(7), 683-694.

[32] Van Ham, H., \& Koppenjan, J. (2001). Building publicprivate partnerships: Assessing and managing risks in port development. Public Management Review, 3(4), 593-616.

[33] Williamson, O.E. 1996. The Mechanisms of Governance. Oxford: Oxford University Press.

[34] Yin, R.K., 2003. Case Study Research: Design and Methods. SAGE Publications.

[35] Zanella, A., Bui, N., Castellani, A., Vangelista, L., \& Zorzi, M. (2014). Internet of things for smart cities. IEEE Internet of Things journal, 1(1), 22-32. 